\title{
Hyrdrogeochemical controls of unconfined groundwater in the southeastern Musashino Terrace, Japan
}

\author{
MINGZHE ZHAO $^{1}$, MASARU YAMANAKA $^{2}$ \\ ${ }^{1,2}$ Advanced Research Institute for the Sciences and \\ Humanities, NihonUniversity, Setagaya-ku 156-8550, \\ Japan
}

The Musashino Terrace, developed in central Tokyo Met., is the largest part of the terrace groups, which are composed mainly of unconsolidated sediments and are overlain by volcanic ash sediments in Quaternary (Kanto Loam). Unconfined groundwater in the terrace system is recharged in the western mountainous area with dominantly $\mathrm{Ca}-\mathrm{HCO}_{3}$ type water, which changes to $\mathrm{Mg}-\mathrm{HCO}_{3}$ type and then to $(\mathrm{Mg}+\mathrm{Na})-\mathrm{HCO}_{3}$ type water as it flows toward the SE. It can be attributed to cation exchange reactions between groundwater and loam clay, taking into the consideration that the change occurs without an increase of dissolved ions (EC) and that the terrace had been affected by seawater intrusion during the most recent marine transgression. Namely, on the exchange substrate (loam clay), $\mathrm{Mg}^{2+}$ and $\mathrm{Na}^{+}$(exchangeable cations), derived from seawater during the transgression, had been exchanged with $\mathrm{Ca}^{2+}$ in recharge groundwater for several thousand years, which resulted in a distributional pattern of exchangeable cations in this area which is concoedant well with the affinity for the loam clay such as $\mathrm{Ca}^{2+}>\mathrm{Mg}^{2+}>\mathrm{Na}^{+}$(displacement chromatography; Appelo and Postma, 1993). Eventually, in this study, the cation distribution in groundwater along the flowpath can be the result of cation exchange reactions reflecting the spatialdistribution of exchangeable cations on the exchange substrate (loam clay).

In contrast, $\mathrm{Mg}-\mathrm{HCO}_{3}$ type groundwater modified its chemical composition to $\mathrm{Ca}-\mathrm{HCO}_{3}$ type along the flowpath partially at the eastern area where the Musashino Terrace is wedged between the Shimosueyoshi Upper Terraces. Considering the fact that groundwater is $\mathrm{Ca}-\mathrm{HCO}_{3}$ type at the upper terrace, the change of chemical composition indicated downward mixing of $\mathrm{Ca}-\mathrm{HCO}_{3}$ typer water with $\mathrm{Mg}-\mathrm{HCO}_{3}$ type groundwater at the Musashino Terrace. 